\title{
COMPARISON OF AGGLUTINATING AND NEUTRALIZING ANTIBODIES TO SEROVAR HARDJO IN SOWS IMMUNIZED WITH TWO COMMERCIAL WHOLE CULTURE POLIVALENT ANTI-LEPTOSPIRA BACTERINS
}

\author{
Francisco Rafael Martins Soto ${ }^{1 *}$; Sônia Regina Pinheiroº ${ }^{2}$ Zenaide Maria Morais²; ${ }^{2}$ Amane Paldês Gonçales²; \\ Sérgio Santos de Azevedo ${ }^{3}$; Fernanda Bernardi' ${ }^{1}$; Sebastião Rodrigues Camargo ${ }^{1}$; Silvio Arruda Vasconcellos ${ }^{2}$ \\ ${ }^{1}$ Centro de Vigilância Sanitária e Controle de Zoonoses “Tereza Rodrigues de Camargo", Ibiúna, SP, Brasil; ${ }^{2}$ Departamento \\ de Medicina Veterinária Preventiva e Saúde Animal, Faculdade de Medicina Veterinária e Zootecnia, \\ Universidade de São Paulo, São Paulo, SP, Brasil; ${ }^{3}$ Unidade Acadêmica de Medicina Veterinária, Universidade \\ Federal da Paraíba, Patos, PB, Brasil.
}

Submitted: June 08, 2007; Returned to authors for corrections: December 07, 2007; Approved: July 16, 2008.

\begin{abstract}
It was performed the comparison of the intensity and duration of agglutinating and neutralizing antibodies to serovar Hardjo in swines vaccinated with two commercial anti-leptospira bacterins. Sows no reactive to 24 Leptospira $s$ serovars in the microscopic agglutination test (MAT) were divided in three groups: Group A $(\mathrm{n}=08)$ : received two vaccine $\mathrm{A}$ doses with 30 days interval, Group $\mathrm{B}(\mathrm{n}=08)$ two vaccine $\mathrm{B}$ doses with 30 days interval and Group $\mathrm{C}(\mathrm{n}=08)$ : control no vaccinated against leptospirosis. Blood samples were collected each 30 days during six months following the first vaccination. The sera were tested by MAT and growth inhibition test (GIT) to serovar Hardjo in order to evaluate respectively agglutinating and neutralizing antibodies. It was found that neutralizing antibodies persisted for a longer time than the agglutinating ones and that the absence of agglutinating antibodies does not means in the absence of the neutralizing. The peaks of agglutinating antibodies was obtained at least 30 days earlier than that produced by neutralizing. The duration of both kinds of antibodies measured differed between the two bacterines tested. The period for inducing neutralizing antibodies against serovar Hardjo indicated that gilts must be immunized with two doses of whole culture anti-leptospira bacterines applied 30 days each other at least 90 days before the first mating. For the maintenance of hight levels of neutralizing antibodies the revaccinations must be performed every six months after the first vaccination .
\end{abstract}

Key-words: swine, leptospirosis, immunity, bacterines, vaccination.

\section{INTRODUCTION}

Immune responses of swine to leptospira bacterins have been difficult to evaluate because the majority of vaccinated animals present either low or no microscopic agglutination test (MAT) titer following vaccination (22). The MAT measures primarily IgM, which is less effective for host protection than IgG (10). Neutralizing antibodies, primarily IgG, can be demonstrated either by the hamster passive-protection test or the growth-inhibition test $(13,22,23)$
Hamster passive-protection test or potency tests with challenge in hamsters can be used only for serovars Grippotyphosa and Pomona, which are pathogenic for these animals but not for Hardjo which infects hamsters without causing consistent death patterns (10)

Bacterins used in prevention of swine leptospirosis are inactivated cultures of several serovars that include Pomona, Icterohaemorrhagiae, Hardjo, Canicola, Grippotyphosa and Bratislava. Dobson and Davos (6) evaluated post vaccination agglutinin titers persistency during four months after bacterin

*Corresponding Author. Mailing address: Center for Sanitary Surveillance and Zoonoses Control "Tereza Rodrigues de Camargo", Estrada da Vargem do Salto- Km 4,5- Bairro dos Paes. CEP18150-000 Caixa Postal 34, Ibiúna, SP, Brasil. Tel.: 11-5576-4537 Fax: 112-5572-4711. E-mail: chicosoto@ig.com.br 
injection. Avila (2) investigated the levels of anti-leptospirosis agglutinins in swine vaccinated with one or two doses of a bacterin during 90 days following the first vaccination. Nguyen et al. (14) detected significant differences in agglutinin production in piglets vaccinated against swine leptospirosis and associated this immune response variation to breed differences.

The most prevalent leptospira serovars found in serologic surveys performed in swine herds in Brazil are Pomona, Icterohaemorrhagiae and Bratislava $(7,11,16,18,19)$ but reactions to serovar Hardjo were only observed in a swine herd from São Paulo state (3). This is the most important serovar in bovines in the country, so the possibility of its introduction in swine breeding farms must be considered.

Although the immune response to anti-leptospira vaccination has already been evaluated by MAT with live antigens, it is known that neutralizing protective antibodies levels do not have straight correspondence to agglutinin antibodies titers $(12,20)$, so the absence of agglutinin antibodies does not mean absence of protection.

Tripathy et al. (21) developed the Growth Inhibition Test (GIT) that measures the level of neutralizing protective antibodies after vaccination. The proposed test was applied to the sera of several vaccinated animal species as rabbits, cattle (21), hamsters (20) and buffaloes (12) but until now it was not applied to swines.

As the impact of leptospirosis in swine herds is mainly the drawnback in reproduction efficiency, the knowledge of the behavior of neutralizing anti-leptospira antibodies against serovar Hardjo in sows vaccinated against leptospirosis for the first time will be useful for setting strategic immunizing programs according to the phase of females reproduction .

The present investigation was conducted to evaluate agglutinating and neutralizing antibodies against the serovar Hardjo in groups of swine vaccinated with two commercial whole culture anti-leptospirosis bacterins.

\section{MATERIALAND METHODS}

This experiment was performed in a commercial swine herd with 180 sows, located in at Ibiúna municipality, São Paulo State, Brazil, during eight months from December 2005 to August 2006. Twenty four cross bred sows (Sus scrofa), Landrace x Large White, 230 days old, at first parturition, which had never been vaccinated against leptospirosis and characterized as not reagent to MAT, were selected from the herd and used as experimental animals. Sows were submitted to clinical examination to check body conditions and absence of injuries. Clinical history was obtained from individual files and this selection took 30 days. The animals were maintained in a pen with three meters high and 1 swine $/ 2.5 \mathrm{~m}^{2}$, and separated in groups of four animals. Each sow was daily fed with $2.2 \mathrm{Kg}$ of commercial swine food divided in two meals. Water was ad libitum in an automatic drinking system. Risk to leptospira infection was prevented with adequate liquid waste destination, rodent control, and daily hygiene and disinfection with quaternary ammonium compounds.

Uncontrolled leptospira infection was monitored with clinical surveillance and microscopic agglutination test using 24 leptospira serovars in the non vaccinated control group.

Group A $(n=08)$ received two doses of commercial antileptospira bacterin A, with 30 days interval; Group B $(n=08)$ received two doses of the commercial anti-leptospira bacterin $\mathrm{B}$ with 30 days interval and Group $\mathrm{C}(\mathrm{n}=08)$ was the non-vaccinated control. Group sizes were designated to attend the statistical necessity, as variables in study were quantitative and expressed in arithmetic mean.

Bacterins were intramuscularly injected at the neck muscle in volumes of $5.0 \mathrm{ml}$ and $3.0 \mathrm{ml}$ each animal, according to manufacturer recommendation for groups $\mathrm{A}$ and $\mathrm{B}$ respectively at first vaccination and booster dose.

Commercial anti-leptospira bacterins named A and B of different commercial brands and containing whole bacteria were selected because they are the most used in Brazilian swine industry and both contained six serovars Pomona, Icterohaemorrhagiae, Hardjo, Canicola, Grippotyphosa and Bratislava, the most common ones in serologic survey performed in Brazilian pig farms (18).

Blood collection for serologic evaluation was performed using cranial caval vein punction, simultaneously to application of bacterin, and then within 30 days interval up to six months after first vaccination. Collections were made aseptically using disposable needles (size 40X12). Technicians who helped in this collection and those who made laboratory diagnosis did not have access to data of treated or control groups.

MAT were performed according Cole et al. (5) and Galton et al. (9). Live culture of 22 pathogenic and two saprophytic leptospira serovars were used: Australis, Bratislava, Autumnalis, Butembo, Castellonis, Bataviae, Canicola, Whitcombi, Cynopteri, Sentot, Grippotyphosa, Hebdomadis, Copenhageni, Icterohaemorrhagiae, Panama, Pomona, Pyrogenes, Wolffi, Hardjo, Shermani, Tarassovi, Javanica, Andamana and Patoc. The cutoff point for sera trial was 1:100 dilution of serum-antigen mixture. Reacting sera were individually titrated using several different geometric dilutions. Agglutinin titer was the reverse of higher dilution with $50 \%$ leptospira agglutination.

Blood samples results were analyzed comparing agglutinin and neutralizing antibodies mean titers $(1,24)$.

Neutralizing antibodies levels were measured by the in vitro leptospira growth inhibition test $(12,20,22)$. The protocol was adjusted to laboratory conditions, using four to eight days old cultures in liquid modified EMJH media (21). Serovar Hardjo was used for GIT test because it is not a pathogenic serovar for hamsters (20) and couldn't be tested in challenge tests. Neutralizing antibodies titers were calculated according to Reed and Müench (17). Arithmetic means of reactions detected in 
control group, value $=0.150$, were considered unspecific and subtracted of the results observed in vaccinated groups for Leptospira Growth Inhibitor antibodies.

Agglutinin antibodies titers were expressed in base 10 logarithms. Value 1 was attributed to non reagent animals, and value 1 was added to the calculated base 10 logarithms for titers of $100,200,400,800,1600$ and 3200 , resulting in $\log 2.004,2.303$, $2.603,2.904,3.204$ and 3.505 , respectively.

For overall comparison of arithmetic means of agglutinins and leptospira growth inhibitor antibodies titers between experimental groups, the Kruskall Wallis test was used. For multiple comparisons Mann-Whitney U test was performed using the software SPSS for Windows version 12.0. Significance level was $5 \%$. Confidence intervals (95\%) of anti-leptospira neutralizing antibodies were calculated according to Pizzi (15).

\section{RESULTS}

Control group $\mathrm{C}$ remained as non reagent for the 24 leptospira serovars used at MAT test during all evaluation period in all seven blood collections.

Fig. 1 shows the agglutinins level promoted by the two commercial bacterins evaluated. It is possible to see that both bacterins stimulated a low response after the first vaccination. On the first 30 days after the first vaccination a low level of agglutinins was found only for bacterin A, and this response decreased to zero on the $60^{\text {th }}$ post first vaccination day. Thirty days after the second vaccination both bacterins promoted an increase in the agglutinin levels, reaching the highest values at ninety days after the first vaccination. At 90 days after first vaccination, the reagent rates, MAT $\geq 2.004$ differed from bacterins for serovar Hardjo $(\mathrm{p}<0.001)$. On the $120^{\text {th }}$ day after the first vaccination, there was a small decrease in the agglutinin

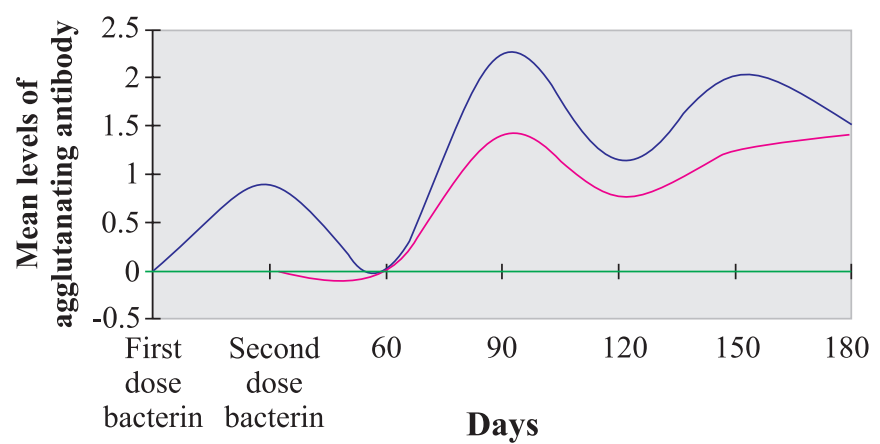

- Commercial bacterin A - Commercial bacterin B - Group C

Figure 1. Mean of agglutinating antibody levels expressed as $\log _{10}$ for Hardjo serovar in sows immunized against leptospirosis with two commercial whole culture bacterins according to the bacterin and the day of blood collection after first vaccination. level for the two bacterins but on the last blood collection, six months after the first vaccination, the level of agglutinins was still high and identical for both vaccines.

Fig. 2 shows the level of neutralizing antibodies against serovar Hardjo measured by GIT for the two commercial bacterins evaluated. On the $30^{\text {th }}$ day after the first vaccine dose the bacterin A promoted a higher response than bacterin B, but the difference was not significant. On the $60^{\text {th }}$ day after the first vaccine dose, the level of neutralizing antibodies to serovar Hardjo was almost the same for the two bacterins tested. From $60^{\text {th }}$ to the $120^{\text {th }}$ day after first vaccination, the neutralizing antibodies curves showed an increasing phase for the two bacterins tested achieving the highest values on the $120^{\text {th }}$ post first vaccination day for both bacterins, but the level presented by bacterin $A$ was higher than $B(p=0.021)$. From $120^{\text {th }}$ to $180^{\text {th }}$ post first vaccination day, a decreasing phase of the neutralizing antibodies was observed for both bacterins, with a strong difference between the two bacterins. While for bacterin $\mathrm{B}$ almost no protection was observed after the $150^{\text {th }}$ post first vaccination day, the neutralizing antibodies due to bacterin A were still high and remained fixed in the 0.3 value, indicating that this value could persist for more than six months after the first vaccination.

\section{DISCUSSION}

The presence of anti-leptospira agglutinin titers during four months after first vaccination observed at the present work for serovar Hardjo with two commercial bacterins was also verified by Dobson and Davos (6), Whyte et al. (25), Frantz et al. (8)

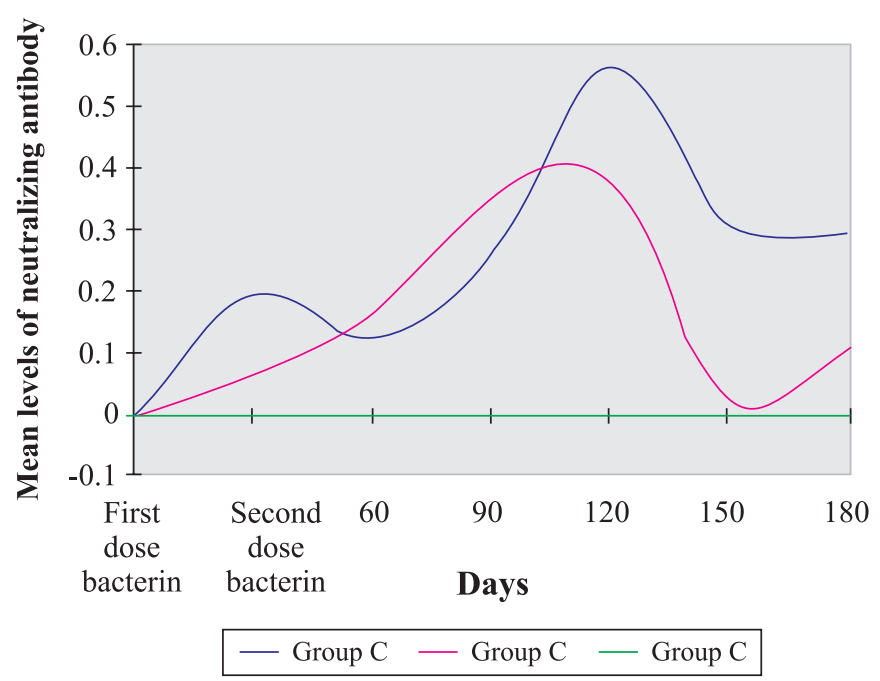

Figure 2. Mean of neutralizing antibody levels expressed as $\log _{10}$ for Hardjo serovar in sows immunized against leptospirosis with two commercial whole culture bacterins according to the bacterin and the day of blood collection after first vaccination 
and Bey and Johnson (4). Ávila (2) tested experimental swine anti-leptospira bivalent bacterins, produced with the serovars Pomona and Canicola, and observed agglutinin titers variations until 90 days after first vaccination, and the highest titer was at $60^{\text {th }}$ post first vaccination day.

Sows neutralizing antibodies titers for serovar Hardjo confirmed the neutralizing antibodies persistency in all six evaluations performed after first vaccination with commercial bacterins even with low titers, mainly for bacterin B. There were differences between vaccines $A$ and $B$, at the sixth blood collection $(p=0.021)$.It was shown the occurrence of neutralizing antibodies peak production at 120 days after first vaccination for both bacterins and high neutralizing antibodies titers persistency for bacterin A at 150 and 180 days after first vaccination, with values of 0.310 and 0.292 in GIT expressed as $\log _{10}$.

Results obtained in this investigation indicated that neutralizing antibodies persisted longer than the agglutinating ones, indicating that the absence of agglutinating antibodies does not mean absence of protection (12). The agglutinating and neutralizing antibodies levels produced by the two bacterins differed in the highest values for almost 30 days. In fact, peaks of agglutinating antibodies (MAT) were obtained always 30 days earlier than that found for neutralizing ones (GIT).

The study demonstrated that the protection of sows against leptospirosis varies according to the vaccine applied. The period for inducing immunity against leptospirosis due to neutralizing antibodies indicated that gilts must be immunized with two vaccine doses applied at an interval of 30 days, at least 90 days before the first mating, achievering the first pregnancy with enough protection against the disease. For the maintenance of a sufficient level of neutralizing antibodies revaccinations must be performed every six months after the first vaccine dose.

\section{RESUMO}

\section{Comparação de anticorpos aglutinantes e neutralizantes do sorovar hardjo em fêmeas suínas imunizadas com duas bacterinas anti- leptospira comerciais}

Foi efetuada a comparação entre a intensidade e duração dos níveis de anticorpos neutralizantes e aglutinantes para o sorovar Hardjo em fêmeas suínas vacinadas com duas bacterinas comerciais anti-leptospirose. Animais caracterizados como não reatores para 24 sorovares de Leptospira sp pelo teste de soroaglutinação microscópica (SAM) e que nunca haviam sido vacinados contra a leptospirose foram divididos em três grupos: grupo $\mathrm{A}(\mathrm{n}=08)$ : recebeu duas doses, em intervalo de 30 dias, de bacterina comercial anti-leptospirose $A$; grupo $B(n=08)$ : recebeu duas doses, em intervalo de 30 dias de bacterina comercial antileptospirose $\mathrm{B}$ e grupo $\mathrm{C}(\mathrm{n}=08)$ : controle, não vacinado contra a leptospirose. As colheitas de sangue foram efetuadas a cada 30 dias durante seis meses a partir da primeira vacinação. Os soros foram submetidos aos testes da SAM e de inibição do crescimento de leptospiras in vitro (ICL) para avaliar, respectivamente, os níveis de anticorpos aglutinantes e neutralizantes. Foi constatado que os anticorpos neutralizantes persistem por mais tempo que os aglutinantes e que a ausência de anticorpos neutralizantes não corresponde a ausência dos aglutinantes. Os picos de anticorpos aglutinantes foram obtidos pelo menos 30 dias antes dos produzidos pelos neutralizantes. Houve diferença nos níveis de anticorpos neutralizantes induzidos pelas duas bacterinas testadas. $\mathrm{O}$ período de indução de anticorpos neutralizantes contra o sorovar Hardjo indica que marrãs devem ser imunizadas com duas doses de bacterina antileptospirose aplicadas com 30 dias de intervalo e pelo menos 90 dias antes da primeira cobertura. A manutenção de níveis elevados de anticorpos neutralizantes exige revacinações semestrais.

Palavras chave: leptospirose, suínos, vacinação, imunidade, bacterinas.

\section{REFERENCES}

1. Alves, C.J.; Vasconcellos, S.A.; Camargo, C.R.A.; Morais, Z.M (1996). Influência de fatores ambientais na proporção de caprinos soro-reagentes para a leptospirose em cinco centros de criação do Estado da Paraíba. Arq. Inst. Biol. São Paulo, 63: 11-18.

2. Ávila, F.A. (1979). Avaliação da resposta imunitária humoral em suínos vacinados experimentalmente contra os sorotipos pomona e canícola, São Paulo, 83 p. (Ph.D. Thesis. Instituto de Ciências Biomédicas, USP).

3. Azevedo, S.S.; Soto, F.R.M.; Morais, Z.M.; Pinheiro, S.R.; Vuaden, E.R.; Batista, C.S.A.; Souza, G.O.; Delbem, A.C.B.; Gonçales, A.P.; Vasconcellos, S.A. (2006). Frequency of anti leptospires agglutinins in sows from a swine herd in the Ibiúna Municipality, State of São Paulo, Brazil. Arq. Inst. Biol., 73 (1): 97-100.

4. Bey, R.F.; Johnson, R.C. (1993). Leptospiral vaccines: immunogenicity of protein free medium cultivated whole cell bacterians in swine. Am. J. Vet. Res., 12: 2299-2301.

5. Cole, J.R.; Sulzer, C.R.; Pulssely, P.R. (1973). Improved microtechnique for the leptospiral microscopic aglutination. J. Appl. Microb., 6: 976-980

6. Dobson, K.J.; Davos, D.E. (1975). Leptospiral titres in pigs after vaccination. Austr. Vet. J., 9: 443-444.

7. Favero, A.C.M.; Pinheiro, S.R.; Vasconcellos, S.A.; Morais, Z.M.; Ferreira, F.; Ferreira Neto, J.S. (2002). Sorovares de leptospiras predominantes em exames sorológicos de bubalinos, ovinos, caprinos, eqüinos, suínos e cães de diversos estados brasileiros. Ciênc. Rur., 4: 613-619.

8. Frantz, J.C.; Hanson, L.E.; Brown, A.L. (1989). Effect of vaccination with a bacteria containing Leptospira interrogans serovar bratislava on the breeding performance of swine herds. Am. J. Vet. Res., 7: 1044-1047.

9. Galton, M.M.; Sulzer, C.R.; Santa Rosa, C.A.; Fields, M.J. (1965). Application of a microtechnique to the agglutination test for leptospiral antibodies. J. Appl. Microb., 1: 81-85.

10. Hanson, L.E. (1977). Immunology of bacterial diseases, with special reference to leptospirosis. J. Am. Vet. Med. Assoc., v. 170, n. 9, p. 991-994. 
11. Langoni, H.; Cabral, K.S.M.; Jacobi, H. (1995). Inquérito soroepidemiológico para leptospirose suína. In: Congresso Brasileiro de Veterinários Especialistas em Suínos, Blumenal, Anais... Blumenal, p. 153.

12. Nardi, G. (2005). Perfil sorológico de anticorpos anti-Leptospira spp em búfalas (Bubalus bubalis) vacinadas com tipos de vacinas comerciais anti-leptospirose (Bacterina e Membrana externa), São Paulo, 89 p. (MSc. Thesis. Faculdade de Medicina Veterinária e Zootecnia, Universidade de São Paulo).

13. Negi, S.K.; Myers, W.L.; Segre, D. (1971). Antibody response of cattle to Leptospira Pomona: Response as measured by Hemagglutination, Microscopic Agglutination and Hamster Protection Tests. Am. J. Vet. Res., v. 32, p. 1915-1920.

14. Nguyen, V.P.; Wong, C.W.; Hinch, G.N.; Singh, D.; Colditz, I.G. (1998). Variation in the immune status of two Australian pig breeds. Austr. Vet. J., 76: 613-617.

15. Pizzi, M. (1950). Sampling variation of the fifty percent end-point, determined by Reed-Muench (Behrens) method. Hum. Biol., 3: 151190.

16. Ramos, A.C.F.; Lilenbaum, W. (2002). Fatores que influenciam na ocorrência de aglutininas anti-Leptospira em suínos de criação tecnificada do Estado do Rio de Janeiro. Rev. Bras. Med. Vet., 24: 20-29.

17. Reed, L.J.; Muench, H. (1938). A simple method of estimating fifty percent endpoints. Am. J. Hyg., 27: 493-497.

18. Shimabukuro, F.H.; Domingues, P.F.; Langoni, H.; Silva, A.V.; Pinheiro, J.P.; Padovani, C.R. (2003). Pesquisa de suínos portadores renais de leptospiras pelo isolamento microbiano e reação em cadeia pela polimerase em amostras de rins de animais sorologicamente positivos e negativos para leptospirose. Braz. J. Vet. Res. Anim. Sci., 40 (4): $243-253$.

19. Souza, A.S. (2000). Estudo da prevalência de Leptospira interrogans em reprodutores suínos em produção e aspectos epidemiológicos da infecção em Goiás, Goiás, 74 p. (MSc. Thesis - Universidade Federal de Goiás, Escola de Veterinária)

20. Tabata, R.; Scanavini Neto, H.; Zuanaze, M.A.F.; Oliveira, E.M.D.; Dias, R.A.; Morais, Z.M.; Ito, F.H.; Vasconcellos, S.A. (2002). Cross neutralizing antibodies in hamsters vaccinated with leptospiral bacterins produced with three serovars of serogroup sejroe. Braz. J. Microb., 33: 267-270.

21. Tripathy, D.N.; Hanson, L.E.; Krumrey, W.A. (1971). An in vitro growth inhibition test for leptospiral neutralization. Proc. $75^{\text {th }}$ Annu. Meet. U.S. Anim Health Assoc., p. 138-143.

22. Triphaty, D.N.; Hanson, L.E.; Mansfield, M.E. (1973). Growth inhibition test for measurement of immune response of animals vaccinated with leptospiral bacterins. 77 Annu. Meet. U.S. Anim. Health Assoc., Missouri, p. 20-30.

23. Tripathy, D.N.; Smith, A.R.; Hanson, L.E. (1975). Immunoglobulins in cattle vaccinated with leptospiral bacterins. Am. J. Vet. Res., v. 36, p. 1735-1736, 1975.

24. Turner, L.H. (1970). Leptospirosis III. Maintenance, isolation and demonstration of leptospires. Trans. Royal Soc. Trop. Med. Hyg., 64: 623-646.

25. Whyte, P.B.; Ratccliff, R.M.; Cargill, C.; Dobson, K.J. (1982). Protection of pregnant swine by vaccination against leptospira infection. Austr. Vet. Journal., 59: 41-45. 